\title{
Colorimetric study of zinc oxide poly(methyl methacrylate) nanocomposite - new biomaterial for denture bases
}

\author{
Ocena kolorystyczna nanokompozytu tlenku cynku z polimetakrylanem \\ metylu - nowego biomateriału na płyty protez stomatologicznych
}

\author{
Mariusz Cierech', Marcin Szerszeñ', Jacek Wojnarowicz ${ }^{2}$, Witold Lojkowski², \\ Jolanta Kostrzewa-Janicka ${ }^{1}$, Elżbieta Mierzwińska-Nastalska ${ }^{1}$ \\ ${ }^{1}$ Katedra Protetyki Stomatologicznej Warszawskiego Uniwersytetu Medycznego \\ Department of Prosthetic Dentistry, Medical University of Warsaw \\ Kierownik: prof. dr hab. n. med. Jolanta Kostrzewa-Janicka \\ ${ }^{2}$ Laboratorium Nanostruktur, Instytut Wysokich Ciśnień, Polska Akademia Nauk \\ Laboratory of Nanostructures, Institute of High Pressure Physics, Polish Academy of Sciences \\ Kierownik: prof. dr hab. inż. Witold Łojkowski
}

KEY WORDS:

dentures, zinc oxide nanoparticles, polymethyl metacrylate (PMMA), colorimetric study

\section{Summary}

Introduction. The addition of nanoparticles to poly(methyl methacrylate) (PMMA) changes the colour and optical properties of the new biomaterial, which might result in limited or impossible application of the aforementioned modification in production of denture bases.

Aim of the study. To determine the manner in which incorporation of zinc oxide changes the colour properties of PMMA and of the permanence of the obtained colour after subjecting the material to colouring agents.

Material and methods. The test group was composed of $2.5 \%, 5 \%$, and $7.5 \%$ of PMMA$\mathrm{ZnO}$ nanocomposites, the control group was Superacryl Plus, a thermally polymerised acrylic material (Spofa Dental, Jicin, Czech Republic). The colouring agents used in the test were coffee $(C O)$ and red wine $(R W)$, in the control group it was distilled water $(D W)$. The samples were subjected to a colorimetric test with the use of a
HASŁA INDEKSOWE:

protezy stomatologiczne, nanocząstki tlenku cynku, polimetakrylan metylu (PMMA), badanie kolorymetryczne

\section{Streszczenie}

Wprowadzenie. Dodatek nanoczastek do polimetakrylanu metylu (PMMA) zmienia kolor $i$ wtaściwości optyczne nowego biomateriatu, co może skutkować ograniczeniami lub niemożnościa zastosowania $w / w$ modyfikacji $w$ wykonawstwie plyt protez stomatologicznych.

Cel pracy. Określenie w jaki sposób inkorporacja tlenku cynku zmienia właściwości kolorystyczne PMMA i jaka jest trwałość uzyskanego koloru po poddaniu tworzywa działaniu czynników barwiacych.

Material i metody. Grupa badana sktadała sie z 2,5\%, 5\% oraz 7,5\% nanokompozytów PMMA - ZnO, grupa kontrolna to polimeryzowane termicznie tworzywo akrylowe Superacryl Plus (Spofa Dental, Jicin, Czech Republic). Czynniki barwiace uzyte $w$ badaniu to kawa (CO) oraz czerwone wino $(R W)$, kontrole stanowita woda destylowana $(D W)$. Próbki byly poddane badaniu kolorymetrycznemu z wykorzystaniem cyfrowe- 
digital colorimeter and recorded within the Red/ Green/Blue (RGB) colour space.

Results. The change of colour for PMMA and individual nanocomposites increased in line with the content of nanoparticles. In the colour permanence test, considerably higher $\Delta E$ values were observed for samples coloured with red wine. In comparison to pure PMMA, smaller concentrations of nanocomposites behaved similarly or were discoloured to a slightly greater extent. The $7.5 \%$ nanocomposite behaved differently: they proved to be much less stable in terms of colour compared to other nanocomposites.

Conclusions. 1. The modification of PMMA with $\mathrm{ZnO}$ nanoparticles is acceptable in aesthetic terms. However, the slight whitening of the material must be discussed with the patient before its potential clinical application. 2. Due to the lower colour stability of the material, the use of the $7.5 \%$ nanocomposite needs to be confronted with the possible benefits arising from its positive microbiological action.

\section{Introduction}

The demands of the patients treated with prosthetic restorations are continually growing. They concern not only the durability of the applied solutions but also, and perhaps foremost, broadly understood aesthetics. This results, among others, from universal access to the Internet and, what follows, numerous social networking websites, where a beautiful smile is an indispensable condition for attractiveness and is more and more frequently perceived as an integral part of one's self-esteem. Therefore, prosthetic treatment can be considered a success when the function is restored and satisfactory aesthetics is achieved at the same time. In the case of entirely or partly toothless patients, removable prostheses remain the most common go kolorymetru i zapisywane $w$ przestrzeni barw Red/Green/Blue (RGB).

Wyniki. Zmiana koloru dla PMMA i poszczególnych nanokompozytów wzrastała adekwatnie do zawartości nanoczastek. W badaniu trwałości kolorów zaobserwowano znacznie wyższe wartości $\Delta E$ dla próbek barwionych czerwonym winem. W porównaniu do czystego PMMA mniejsze stężenia nanokompozytów zachowywaty sie podobnie lub ulegaty niewiele większemu przebarwieniu. Inaczej zachowywat się 7,5\% nanokompozyt, który okazat się znacznie mniej stabilny kolorystycznie w porównaniu do pozostatych nanokompozytów.

Wnioski. 1. Modyfikacja PMMA nanoczastkami $\mathrm{ZnO}$ jest akceptowalna pod względem estetycznym. Niewielkie zbielenie materiatu musi być jednak przedyskutowane z pacjentem przed potencjalnym zastosowaniem klinicznym. 2. Ze względu na mniejsza stabilność kolorystyczna materiatu, zastosowanie $7.5 \%$ nanokompozytu musi być skonfrontowane z ewentualnymi zyskami wynikajacymi z pozytywnego działania mikrobiologicznego.

\section{Wstęp}

Wymagania pacjentów leczonych protetycznie stale wzrastają. Dotyczą one trwałości zastosowanych rozwiązań, ale także a może przede wszystkim szeroko rozumianej estetyki. Wynika to między innymi z powszechności dostępu do internetu, a tym samym licznych portali społecznościowych, gdzie piękny uśmiech jest nieodzownym elementem atrakcyjności i coraz częściej nierozerwalnie związany z poczuciem własnej wartości. O sukcesie $\mathrm{w}$ leczeniu protetycznym można zatem mówić gdy spełnione są jednocześnie warunki odnośnie przywrócenia funkcji oraz uzyskania zadowalającej estetyki. W przypadku pacjentów bezzębnych lub z rozległymi brakami zębowymi nadal najczęściej wykonywanymi 
type of restorations. A satisfactory aesthetic effect depends on many factors, but it can be achieved at a level similar to that of fixed restorations. What is an extremely significant element is pink aesthetics, i.e. a faithful imitation of the colour, shape and anatomical details of gums and oral mucosa. The prosthesis base is normally made of poly(methyl methacrylate) (PMMA). This material can be modified with both organic and inorganic substances to improve its mechanical, tribological, aesthetic, or microbiological properties. ${ }^{1}$ In times of the developing nanotechnology, substances are increasingly more often doped on the nanoscale in order to change specific properties of the material. The most desirable feature of such a modification is microbiological activity, which would reduce the possibility of the bacterial \& fungal biofilm accumulation on the prosthesis base. The modification that is best known today is the use of silver nanoparticles with proved antibacterial and antifungal activity. $^{2}$ What limitsthe application of the material created with this method in everyday clinical practice is the dark brown shade, which disqualifies it in terms of aesthetics. Each addition of nanoparticles changes not only the colour to a smaller or larger extent but also the optical properties of PMMA. The addition of nanosilver in composite materials may also affect the stability of the biomaterial in the oral cavity by increasing the release of metal ions with all their positive and negative effects. $^{3}$ In their earlier papers, the authors described the preparation, and determined the mechanical, microbiological, and cytotoxic properties of PMMA modified with zinc oxide nanoparticles. ${ }^{4-7}$ The feature that will largely determine the potential application of the aforementioned modification in clinical trials is colour and its stability when subjected to the colouring media that are present in the oral cavity environment during the everyday use of protheses. uzupełniniami są protezy ruchome. Uzyskanie zadowalającego efektu estetycznego zależy od wielu czynników, ale jest możliwe na podobnym poziomie jak w przypadku uzupełnień stałych. Elementem niezwykle istotnym jest estetyka różowa, czyli wierne naśladowanie koloru, kształtu oraz szczegółów anatomicznych dziąseł oraz błony śluzowej jamy ustnej. Płyta protezy wykonana jest najczęściej z polimetakrylanu metylu (PMMA). Tworzywo to może być modyfikowane substancjami organicznymi jak i nieorganicznymi w celu poprawienia właściwości mechanicznych, trybologicznych, estetycznych czy mikrobiologicznych. ${ }^{1} \mathrm{~W}$ dobie stale rozwijającej się nanotechnologii coraz częściej domieszkuje się substancje w skali nano, aby zmienić określone właściwości tworzywa. Najbardziej pożądaną cechą takiej modyfikacji jest aktywność mikrobiologiczna, która zmniejszałaby możliwość gromadzenia na płycie protezy biofilmu bakteryjno-grzybiczego. Obecnie najlepiej poznaną modyfikacją jest wykorzystanie nanocząstek srebra o udowodnionej aktywności przeciwbakteryjnej i przeciwgrzybiczej. ${ }^{2}$ Cechą tak wytworzonego materiału, która utrudnia zastosowanie go w codziennej praktyce klinicznej jest brunatny odcień, który dyskwalifikuje go pod względem estetycznym. Każdy dodatek nanocząstek w mniejszym lub większym stopniu zmienia kolor, ale także właściwości optyczne PMMA. Dodatek nanosrebra w materiałach kompozytowych może także wpłynąć na stabilność biomateriału w środowisku jamy ustnej zwiększając uwalnianie jonów metali ze wszystkimi pozytywnymi jak i negatywnymi tego skutkami. ${ }^{3} \mathrm{~W}$ poprzednich artykułach autorzy opisali przygotowanie, a także określili właściwości mechaniczne, mikrobiologiczne i cytotoksyczne PMMA modyfikowanego nanocząstkami tlenku cynku. ${ }^{4-7}$ Cechą, która w znacznym stopniu będzie decydowała o potencjalnym użyciu powyższej modyfikacji $\mathrm{w}$ badaniach klinicznych jest kolor oraz jego stabilność po 


\section{Aim of the study}

This publication is aimed to determine the manner in which incorporation of zinc oxide changes the colour properties of PMMA and the permanence of the obtained colour after subjecting the material to colouring agents.

\section{Material and methods}

\section{Characteristics of $\mathrm{ZnO}$ nanoparticles}

Zinc oxide nanoparticles ( $\mathrm{ZnO}$ NPs) were obtained with the use of microwave solvothermal synthesis. ${ }^{8,9}$ The method of obtaining $\mathrm{ZnO}$ NPs samples and their characterisation were described in detail in earlier publications of the authors. ${ }^{4-7}$ The $\mathrm{ZnO}$ NPs used were characterised by the average particle size of $\approx 30 \mathrm{~nm}$ (Fig. 1), density of $5.24 \mathrm{~g} / \mathrm{cm}^{3}$, specific surface area of $39 \mathrm{~m}^{2} / \mathrm{g}$, and phase purity (Fig. 2). The tests performed with the use of the scanning electron microscope (SEM) (Fig. 3) and transmission electron microscope (TEM) (Fig. 4) showed a high homogeneity of nanoparticles in terms of both their size and their shape. The characterisation of the $\mathrm{ZnO}$ samples presented herein was performed at an accredited research laboratory with the certificate no. AB 9 (Laboratory of Nanostructures, IHPP PAS, Warsaw, Poland), which operates in accordance with PN-EN ISO/IEC 17025:2018-02.10

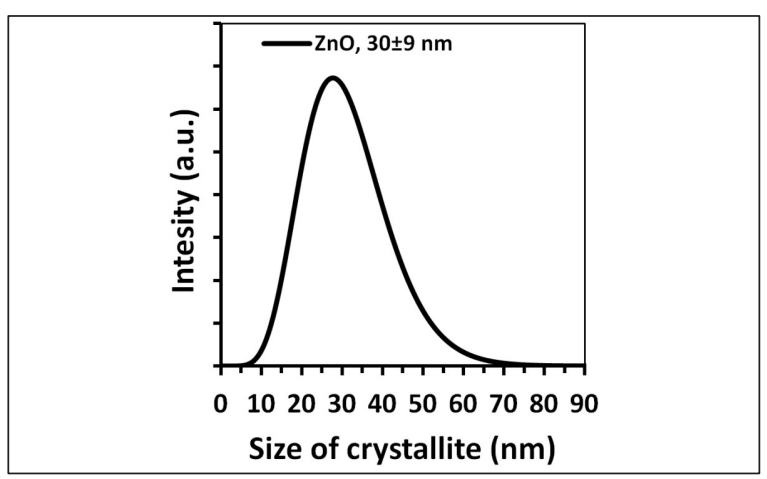

Fig. 1. ZnO NPs size distribution obtained with the use of the Nanopowder XRD application.

Ryc. 1. Rozklad wielkości NC ZnO otrzymany przy użyciu aplikacji Nanopowder XRD. poddaniu działaniu mediów barwiących, obecnych w środowisku jamy ustnej podczas codziennego użytkowania protez.

\section{Cel pracy}

Celem poniższej publikacji jest określenie w jaki sposób inkorporacja tlenku cynku zmienia właściwości kolorystyczne PMMA i jaka jest trwałość uzyskanego koloru po poddaniu tworzywa działaniu czynników barwiących.

\section{Material i metody}

\section{Charakterystyka nanoczastek $\mathrm{ZnO}$}

Nanocząstki tlenku cynku (NC ZnO) otrzymano przy użyciu mikrofalowej syntezy solwotermalnej. ${ }^{8,9}$ Szczegółowy opis metody otrzymania próbek NC ZnO oraz ich charakteryzacji został opisany we wcześniejszych publikacjach autorów. ${ }^{4-7}$ Użyte $\mathrm{NC} \mathrm{ZnO}$ charakteryzowały się średnią wielkością cząstek $\approx 30 \mathrm{~nm}$ (ryc. 1), gęstością $5,24 \mathrm{~g} / \mathrm{cm}^{3}$, powierzchnią właściwą $39 \mathrm{~m}^{2} / \mathrm{g}$ oraz czystością fazową (ryc. 2). Badania skaningowym mikroskopem elektronowym (SEM) (ryc. 3) oraz transmisyjnym mikroskopem elektronowym (TEM) (ryc. 4) wykazały dużą homogenność nanocząstek zarówno w wielkości, jak i kształcie ziaren. Charakterystykę próbek $\mathrm{ZnO}$ zamieszczoną w niniejszym artykule wykonano

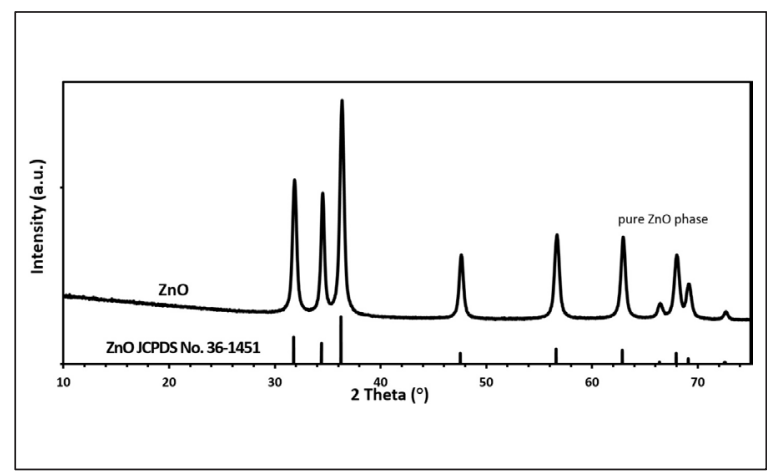

Fig. 2. Results of the ZnO NPs X-ray diffraction. Ryc. 2. Wyniki dyfrakcji rentgenowskiej $N C \mathrm{ZnO}$. 


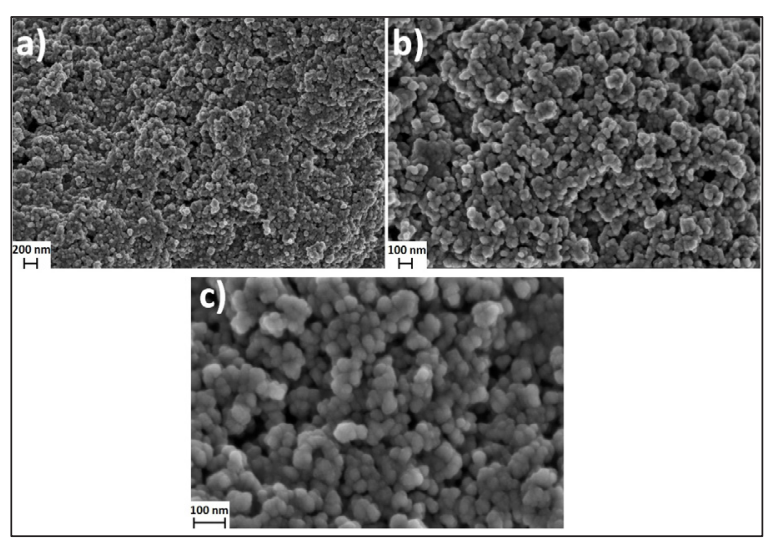

Fig. 3. Representative SEM images of ZnO NPs. Ryc. 3. Reprezentatywne obrazy SEM NC ZnO.

Preparation of poly(methyl methacrylate) modified with $\mathrm{ZnO}$ nanoparticles

A thermally polymerised acrylic material was used for the test (Superacryl Plus; Spofa Dental, Jicin, Czech Republic). The powder-liquid volume ratio recommended by the producer is $3: 1$, which corresponds to $22 \mathrm{~g}$ of the polymer and $10 \mathrm{ml}$ of the liquid monomer. The calculated amount of the nanopowder was suspended in a liquid acrylic resin monomer and subjected to mechanical mixing with a metal spatula for 60 seconds. Afterwards, the calculated amount of PMMA was added to obtain the final weight concentration of $2.5 \%, 5 \%$, and $7.5 \%$. The precise weight content of the individual components is presented in Table 1. Initially, samples sized $13 \times 13 \times 2 \mathrm{~mm}$ were made of modelling wax (Vertex Regular; Vertex-Dental BV, Zeist, The Netherlands) and, in accordance with the standard procedure, transformed into an acrylic material with the use of Class III hard plaster (Stodent; Zhermack). In order to achieve a smooth surface, the samples were covered with a $0.025 \mathrm{~mm}$ thick polyethylene sheet (Divosheet; Vertex-DentalBV). The material was subsequently subjected to conventional thermal polymerisation in a polymeriser (PS-2; P.E.M., Warsaw, Poland) as recommended by the manufacturer (gradual temperature increase

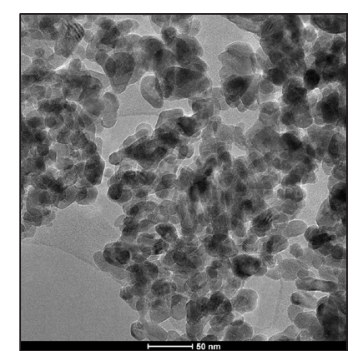

Fig. 4. Representative TEM image of $\mathrm{ZnO}$ NPs. Ryc. 4. Reprezentatywny obraz TEM NC ZnO.

w akredytowanym laboratorium badawczym o numerze certyfikatu AB 1503 (Laboratory of Nanostructures, IHPP PAN, Warsaw, Poland), które funkcjonuje zgodnie z normą PN-EN ISO/IEC 17025:2018-02.10.

Przygotowanie polimetakrylanu metylu modyfikowanego nanoczastkami $\mathrm{ZnO}$

$\mathrm{W}$ badaniu wykorzystano polimeryzowane termicznie tworzywo akrylowe (Superacryl Plus; Spofa Dental, Jicin, Czech Republic). Rekomendowany przez producenta stosunek objętościowy proszku do płynu wynosi 3:1 co odpowiada 22 g polimeru oraz $10 \mathrm{ml}$ płynnego monomeru. Obliczona ilość nanoproszku została zawieszona w płynnym monomerze żywicy akrylowej i poddana mechanicznemu mieszaniu metalową szpatułką przez 60 sekund. Następnie dodano obliczoną ilość PMMA, aby uzyskać końcowe stężenie wagowe 2,5\%, 5\% oraz 7,5\%. Dokładny skład wagowy poszczególnych składników został podany w tabeli 1 . Początkowo próbki o wymiarach $13 \times 13 \times 2 \mathrm{~mm}$ zostały przygotowane $\mathrm{z}$ wosku modelowego (Vertex Regular; Vertex-Dental BV, Zeist, The Netherlands), oraz zamienione przy użyciu standardowej procedury na tworzywo akrylowe z wykorzystaniem twardego gipsu klasy III (Stodent; Zhermack). W celu uzyskania gładkiej powierzchni próbki były pokrywane folią techniczną o grubości 0,025 mm (Divosheet; Vertex-DentalBV). Materiał został następnie poddany konwencjonalnej polimeryzacji 
Tab le 1. Chemical composition of individual nanocomposites

\begin{tabular}{|l|c|c|c|}
\hline \multicolumn{1}{|c|}{ Composition } & $\begin{array}{c}2.5 \% \\
\text { Nanocomposite }\end{array}$ & $\begin{array}{c}5 \% \\
\text { Nanocomposite }\end{array}$ & $\begin{array}{c}7.5 \% \\
\text { Nanocomposite }\end{array}$ \\
\hline ZnO nanopowder & $0.803 \mathrm{~g}$ & $1.605 \mathrm{~g}$ & $2.408 \mathrm{~g}$ \\
\hline PMMA polymer powder & $22 \mathrm{~g}$ & $22 \mathrm{~g}$ & $22 \mathrm{~g}$ \\
\hline PMMA liquid monomer & $10 \mathrm{~g}$ & $10 \mathrm{~g}$ & $10 \mathrm{~g}$ \\
\hline
\end{tabular}

to $97^{\circ} \mathrm{C}$; polymerisation time at temp. of $97^{\circ} \mathrm{C}$ : $30 \mathrm{~min})$. The control group was the acrylic material without addition of nanoparticles.

\section{Comparison of colour of modified and unmo- dified PMMA}

For the purpose of comparing the colour of PMMA with PMMA-ZnO NPs nanocomposite, twenty samples were prepared and divided into four equinumerous groups depending on the weight content of $\mathrm{ZnO}$ NPs. The samples were subjected to a colorimetric test with the use of a digital colorimeter (ColorReader, Datacolor AG Europe, Switzerland) fitted with a wireless Bluetooth interface enabling connection with dedicated software. The data obtained from the device were transmitted to the software and recorded within the RGB colour space. The specifications of the recording device are compliant with the standards adopted by CIE (Commission internationale de l'éclairage International Commission on Illumination) for colorimetric tests, namely the observation angle of $10^{\circ}$ and the illuminant being D65, with the satisfaction of the technical requirements ensured by the built-in light source in the form of 6 LEDs. The RGB colour space consists in an additive synthesis of three constituent colours: $\mathrm{R}$ - red, G - green, B - blue. Mixing the three main colours in an appropriate proportion gives rise to a wide spectrum of secondary colours. The colour record in the RGB model is composed of three successive numbers termicznej $\mathrm{w}$ polimeryzatorze (PS-2; P.E.M., Warsaw, Poland) zgodnie z zaleceniami producenta (stopniowo podnoszona temperatura do $97^{\circ} \mathrm{C}$; czas polimeryzacji $\mathrm{w}$ temp. $97^{\circ} \mathrm{C}$ : $30 \mathrm{~min})$. Grupę kontrolną stanowiło tworzywo akrylowe bez dodatku nanocząstek.

\section{Porównanie koloru modyfikowanego i nie- modyfikowanego PMMA}

W celu porównania koloru PMMA z nanokompozytem PMMA-ZnO NC przygotowano 20 próbek, które podzielono na 4 równoliczne grupy w zależności od wagowej zawartości ZnO NC. Próbki były poddane badaniu kolorymetrycznemu $\mathrm{z}$ wykorzystaniem cyfrowego kolorymetru (ColorReader, Datacolor AG Europe, Switzerland) wyposażonego w bezprzewodowy interfejs Bluetooth do połączenia $\mathrm{z}$ dedykowanym oprogramowaniem. Dane pozyskiwane z urządzenia były transportowane do oprogramowania i zapisywane w przestrzeni barw RGB. Urządzenie rejestrujące posiada specyfikacje zgodne ze standardami przyjętymi przez CIE (Commission internationale de l'éclairage - Międzynarodowa Komisja ds. Oświetlenia) w badaniach kolorymetrycznych w postaci $10^{\circ}$ kąta obserwacji oraz illuminantu D65 - wymagania techniczne są uzyskiwane dzięki wbudowanemu źródle światła w postaci 6 diód led. Model przestrzeni barw RGB polega na addytywnej syntezie trzech składowych barw: R - czerwonej, G - zielonej, B niebieskiej. Zmieszanie wymienionych trzech 
within the range from 0 to 255 , where 0.0 .0 means black, and 255.255.255 means white. Each sample was subjected to five independent colorimetric measurements in various areas and on both sides of the prepared samples. The values obtained in this manner were compiled with the use of descriptive statistics (mean, SD) and then differences in the obtained colours between groups were calculated by means of the $\Delta \mathrm{E}$ parameter according to the following formula:

$$
\Delta E_{R G B}=\sqrt{(\Delta R)^{2}+(\Delta G)^{2}+(\Delta B)^{2}} .
$$

The $\Delta \mathrm{E}$ value is the Euclidean distance between two colours in the colour space, provided that both colours have been described in the same space and it is expressed as a number. An example of the distance $\Delta \mathrm{E}$ in the RGB colour space is shown in Figure 5.

Analysis of colour permanence depending on the external environment

The material prepared while comparing the colour of unmodified and modified PMMA served the purpose of analysing colour permanence depending on the external

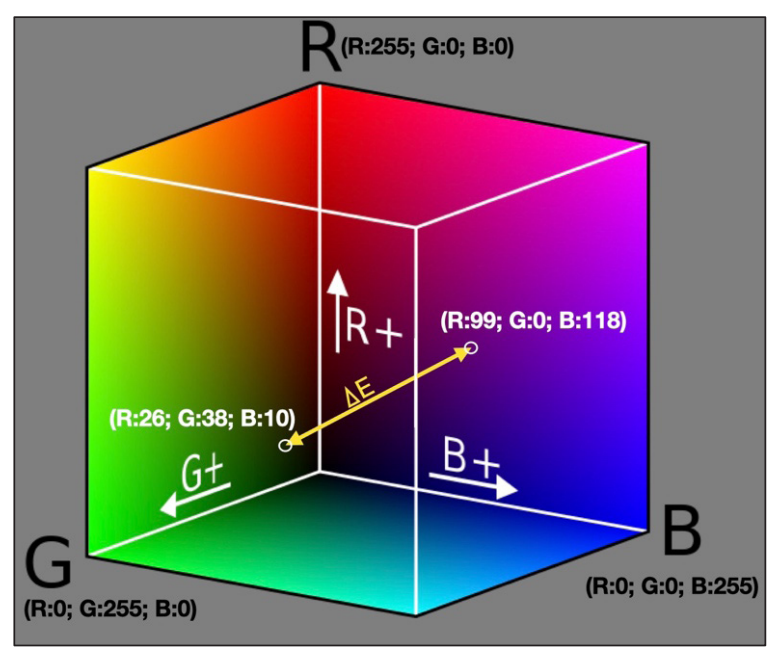

Fig. 5. RGB color space with the selected example of $\triangle E$ distance.

Ryc. 5. Przestrzeń barw RGB wraz z zaznaczona przykładową odległością $\Delta E$. głównych kolorów w odpowiedniej proporcji skutkuje powstawaniem szerokiej gamy barw pochodnych. Zapis koloru w modelu RGB składa się z 3 liczb następujących po sobie, przyjmujących zakres wartości od 0 do 255 , gdzie wartość 0.0 .0 oznacza czarny, a wartość 255.255.255 kolor biały. Każda próbka została poddana 5 niezależnym pomiarom kolorymetrycznym w różnych obszarach oraz z obu stron przygotowanych próbek. Uzyskane w ten sposób wartości zostały opracowane przy pomocy statystyki opisowej (średnia, SD) a następnie obliczono różnice w otrzymanych kolorach pomiędzy grupami wykorzystując parametr $\Delta \mathrm{E}$ korzystając ze wzoru:

$$
\Delta E_{R G B}=\sqrt{(\Delta R)^{2}+(\Delta G)^{2}+(\Delta B)^{2}}
$$

Wartość $\Delta \mathrm{E}$ to Euklidesowa odległość pomiędzy dwoma kolorami w przestrzeni barw o ile oba kolory zostały opisane w tej samej przestrzeni i jest wyrażana $\mathrm{w}$ formie liczby. Przykład odległości $\Delta \mathrm{E}$ w przestrzeni barw RGB został zobrazowany na rycinie 5 .

Analiza trwałości koloru w zależności od środowiska zewnętrznego

W celu analizy trwałości koloru w zależności od środowiska zewnętrznego wykorzystano materiał przygotowany podczas badania porównania koloru niemodyfikowanego oraz modyfikowanego PMMA. Dwadzieścia próbek zostało podzielonych najpierw pod względem wagowej procentowej zawartości $\mathrm{ZnO}$ NC w matrycy PMMA a następnie na trzy grupy w zależności od wykorzystanego środowiska zanurzenia próbek. Wykorzystano dwa roztwory: kawy (CO) oraz czerwonego wina (RW), które wykorzystywane przez pacjentów mogą potencjalnie zmienić zabarwienie płyt protez. Grupę kontrolną stanowiły próbki zanurzone w wodzie destylowanej (DW). Podział ze względu na zawartość ZnO NC, grupy oraz wykorzystane roztwory obrazuje 
Ta b le 2. Division of samples by materials and colouring media

\begin{tabular}{|c|c|c|c|}
\hline $\begin{array}{c}\text { weight } \% \text { content of } \\
\text { ZnO NPs }\end{array}$ & Material code & Storage environment & Group name \\
\hline \multirow{3}{*}{$0 \%$} & \multirow{3}{*}{ PMMA } & Distilled water & $0 \% \mathrm{DW}$ \\
\hline & & Coffee & $0 \% \mathrm{CO}$ \\
\hline & & Red wine & $0 \% \mathrm{RW}$ \\
\hline \multirow{3}{*}{$2.5 \%$} & \multirow{3}{*}{$\begin{array}{c}\text { PMMA-ZnO NPs } \\
2.5 \%\end{array}$} & Distilled water & $2.5 \% \mathrm{DW}$ \\
\hline & & Coffee & $2.5 \% \mathrm{CO}$ \\
\hline & & Red wine & $2.5 \% \mathrm{RW}$ \\
\hline \multirow{3}{*}{$5 \%$} & \multirow{3}{*}{$\begin{array}{c}\text { PMMA-ZnO NPs } \\
5 \%\end{array}$} & Distilled water & $5 \% \mathrm{DW}$ \\
\hline & & Coffee & $5 \% \mathrm{CO}$ \\
\hline & & Red wine & $5 \% \mathrm{RW}$ \\
\hline \multirow{3}{*}{$7.5 \%$} & \multirow{3}{*}{$\begin{array}{c}\text { PMMA-ZnO NPs } \\
7.5 \%\end{array}$} & Distilled water & $7.5 \% \mathrm{DW}$ \\
\hline & & Coffee & $7,5 \% \mathrm{CO}$ \\
\hline & & Red wine & $7.5 \% \mathrm{RW}$ \\
\hline
\end{tabular}

environment. Twenty samples were divided first in terms of weight percentage content of $\mathrm{ZnO}$ NPs in the PMMA matrix, and subsequently into three groups depending on the sample immersion environment. Two solutions were applied: of coffee (CO) and of red wine (RW), which, when used by patients, could potentially change the colour of the prothesis base. The control group contained samples immersed in distilled water (DW). The division by $\mathrm{ZnO}$ NPs content, groups, and solutions used is illustrated in Table 2. The samples were fully immersed in the prepared solutions in separate polystyrene moulds in order to prevent samples from contacting each other, and stored without light access at the temperature of $23^{\circ} \mathrm{C} \pm 1^{\circ} \mathrm{C}$. Colour measurements were performed before the immersion and subsequently after 24, 48, 72, 96, 120, 144, 168 hours. Each series of measurements was preceded with removing tabela 2. Próbki były zanurzane w całości w przygotowanych roztworach $\mathrm{w}$ oddzielnych polistyrenowych formach, aby zapobiec kontaktowaniu się próbek ze sobą i były przetrzymywane bez dostępu światła $\mathrm{w}$ temperaturze $23^{\circ} \mathrm{C} \pm 1{ }^{\circ} \mathrm{C}$. Pomiary kolorów zostały pobrane przed zatopieniem a następnie po 24 , 48, 72, 96, 120, 144, 168 godzinach. Przed każdą serią pomiarów próbki były wyjmowane $\mathrm{z}$ form, spłukiwane wodą destylowaną następnie osuszane bezpyłowymi ręcznikami celulozowymi. Roztwory, w których były zanurzane próbki były wymieniane co 24 godziny. Rozbieżności w otrzymanych kolorach przedstawiono $\mathrm{w}$ postaci parametru $\Delta \mathrm{E}$. Jednostkowe wartości $\Delta \mathrm{R}, \Delta \mathrm{G}$ oraz $\Delta \mathrm{B}$ były obliczane dla każdej próbki, jako różnica pomiędzy wartością uzyskaną przed zamoczeniem oraz po badanym czasie zanurzenia próbki w roztworze. 
the samples from the moulds, rinsing them with distilled water, and drying them with dust-free cellulose towels. The solutions in which the samples were immersed were replaced every 24 hours. The discrepancies in the obtained colours are presented in the form of the $\Delta \mathrm{E}$ parameter. The unit $\Delta \mathrm{R}, \Delta \mathrm{G}$ and $\Delta \mathrm{B}$ values were calculated for each sample as the difference between the value obtained before the immersion and after a given time of sample immersion in the solution.

\section{Results}

Comparison of colour of modified and unmodified PMMA

All tested samples, regardless of the group, demonstrated the highest red colour constituent in the form of the highest values of R parameter and the lowest $\mathrm{B}$ parameter constituents, which accounts for the blue colour. The highest mean constituent recorded was $\mathrm{R}$ axis in the group PMMA-ZnO NPs 7.5\%, which reached the level of 170.92 . The lowest mean constituent recorded was B axis in the group PMMA, which was 95.2. The change of colour for PMMA and individual nanocomposites increased in line with the content of nanoparticles. The change consisted in the gradual whitening of the material in line with the increase in the weight content of $\mathrm{ZnO} \mathrm{NPs}$, which is visible in the decreased discrepancy between the individual RGB constituents and in their higher levels approaching the maximum value of 255.255.255, yet with the still prevalent red colour. The individual means of RGB constituents for each group of samples are presented in Table 3. The calculated $\Delta \mathrm{E}$ parameter indicates the greatest distance (difference) between the group not containing $\mathrm{ZnO}$ NPs (PMMA) and the group containing the largest dopant of $\mathrm{ZnO}$ NPs (PMMA-ZnO NPs 7.5\%) by weight, which reached 67.69 in this research. The smallest discrepancy was recorded between the group PMMA-ZnO NPs

\section{Wyniki}

Porównanie koloru modyfikowanego i niemodyfikowanego PMMA

W przeprowadzonym badaniu wszystkie badane próbki niezależnie od grupy wykazywały największą składową koloru czerwonego w postaci najwyższych wartości parametru $\mathrm{R}$ oraz najmniejsze składowe parametru B - odpowiadającego za kolor niebieski. Najwyższą zanotowaną średnią składową była współrzędna R w grupie PMMA-ZnO NC7,5\% osiągając poziom 170,92. Najniższa zanotowana średnia składowa dotyczyła współrzędnej B w grupie PMMA i wyniosła 95,2. Zmiana koloru dla PMMA i poszczególnych nanokompozytów wzrastała adekwatnie do zawartości nanocząstek. Zmiana polegała na stopniowym zbielaniu materiału wraz ze wzrostem wagowej zawartości $\mathrm{ZnO} \mathrm{NC}$, co jest widoczne w zmniejszonej dyskrepancji pomiędzy poszczególnymi składowymi RGB oraz w ich wyższych poziomach zbliżających się do maksymalnej wartości 255.255.255, jednak wciąż z dominującym kolorem czerwonym. Poszczególne średnie składowych RGB dla każdej grupy próbek przedstawia tabela 3 . Obliczony parametr $\Delta \mathrm{E}$ wskazuje na największą odległość (różnicę) pomiędzy grupą niezawierającą ZnO NC (PMMA) a grupą zawierającą wagowo największą domieszkę ZnO NC (PMMA-ZnO NC7,5\%) w niniejszym badaniu osiągając 67,69. Najmniejszą rozbieżność zanotowano w odniesieniu do grupy PMMA$\mathrm{ZnO} \mathrm{NC5} \%$ i grupy PMMA-ZnO NC7,5\% i wyniosła ona 17,4 . Porównanie poszczególnych grup pod względem parametru $\Delta \mathrm{E}$ obrazuje tabela 4 .

Analiza trwałości koloru w zależności od środowiska zewnętrznego

Badanie wykazało zmianę koloru próbek we wszystkich grupach oraz we wszystkich użytych roztworach. Najmniejsze wartości $\Delta \mathrm{E}$ 
Ta b le 3. Mean values of the RGB axes for the individual groups

\begin{tabular}{|c|c|c|c|c|}
\hline Group & & $\mathrm{R}$ & $\mathrm{G}$ & $\mathrm{B}$ \\
\hline PMMA 0\% & Mean (SD) & $139.48(3.38)$ & $104.40(2.77)$ & $95.20(2.61)$ \\
\hline $\begin{array}{c}\text { PMMA-ZnO NPs } \\
2.5 \%\end{array}$ & Mean (SD) & $151.56(1.08)$ & $120.52(0.92)$ & $117.88(0.93)$ \\
\hline $\begin{array}{c}\text { PMMA-ZnO NPs } \\
5 \%\end{array}$ & Mean (SD) & $161.40(4.11)$ & $132.28(4.95)$ & $131.24(5.63)$ \\
\hline $\begin{array}{c}\text { PMMA-ZnO NPs } \\
7.5 \%\end{array}$ & Mean (SD) & $170.92(1.85)$ & $143.12(3.32)$ & $140.96(3.49)$ \\
\hline
\end{tabular}

0 - min., 255 - max., SD - standard deviation.

Ta b l e 4. Comparison of colour of modified and unmodified PMMA ( $\triangle E$ RGB)

\begin{tabular}{|c|c|c|c|}
\hline & $2.50 \%$ & $5 \%$ & $7.50 \%$ \\
\hline $0 \%$ & 30.33 & 50.56 & 67.69 \\
\hline $2.50 \%$ & - & 20.34 & 37.66 \\
\hline $5 \%$ & - & - & 17.40 \\
\hline $7.50 \%$ & - & - & - \\
\hline
\end{tabular}

$5 \%$ and the group PMMA-ZnO NPs 7.5\%, which was 17.4. The comparison of the individual groups in terms of the $\Delta \mathrm{E}$ parameter is illustrated in Table 4.

Analysis of colour permanence depending on the external environment

The research showed a change in the colour of the samples in all groups and in all solutions used. The lowest $\Delta \mathrm{E} R \mathrm{RBB}$ values were recorded for control groups (samples immersed in DW) and they depended on the percentage content of $\mathrm{ZnO}$ NPs. The smallest change in the colour was achieved for PMMA-ZnO NPs $5 \%$ on the second, fifth and sixth day of the test, and reached the $\triangle \mathrm{E}$ RGB value of 0.45 . A trend of colour change intensification over time during the test was observed in all control groups, with the highest values reached on the seventh day of the test. In the test groups where coffee
RGB zauważono dla grup kontrolnych (próbki zanurzone w DW) i były one uzależnione od procentowej zawartości ZnO NC. Najmniejsza zmiana koloru została uzyskana dla PMMA$\mathrm{ZnO}$ NC5\% w drugiej, piątej i szóstej dobie badania uzyskując wartość $\Delta \mathrm{E}$ RGB 0,45. We wszystkich grupach kontrolnych zauważono tendencję do powiększania się zmian kolorystycznych wraz z czasem przeprowadzanego badania uzyskując największe wartości w 7 dobie badania. W grupach badanych, w których wykorzystano kawę oraz czerwone wino zmiany kolorystyczne zachodziły również przez cały okres trwania badania $z$ tendencją wzrostową. Roztwór czerwonego wina najmocniej wpływał na wartość $\Delta E$ RGB uzyskując maksymalną wartość dla grupy PMMAZnO NC7,5\% wynoszącą 62,66 w 7 dobie badania. Roztwór kawy przebarwiał próbki w zdecydowanie mniejszym stopniu niż 
Ta b le 5. 5 E RGB values for the individual materials and solutions over time

\begin{tabular}{|c|c|c|c|c|c|c|c|c|c|}
\hline & & $24 \mathrm{H}$ & $48 \mathrm{H}$ & $72 \mathrm{H}$ & $96 \mathrm{H}$ & $120 \mathrm{H}$ & $144 \mathrm{H}$ & $168 \mathrm{H}$ & Mean (SD) \\
\hline DW & \multirow{3}{*}{ PMMA } & 0.99 & 2.68 & 2.96 & 1.70 & 2.42 & 3.12 & 3.99 & $2.55(0.98)$ \\
\hline $\mathrm{CO}$ & & 3.74 & 2.17 & 1.84 & 4.67 & 1.54 & 2.68 & 5.69 & $3.19(1.56)$ \\
\hline RW & & 4.73 & 10.09 & 13.42 & 16.69 & 21.17 & 27.19 & 34.45 & $18.25(10.21)$ \\
\hline DW & \multirow{3}{*}{$\begin{array}{c}\text { PMMA- } \\
\mathrm{ZnO} \text { NPs } \\
2.5 \%\end{array}$} & 1.09 & 227 & 2.01 & 0.89 & 1.41 & 1.08 & 1.94 & $1.53(0.54)$ \\
\hline $\mathrm{CO}$ & & 2.33 & 4.00 & 3.06 & 4.34 & 4.84 & 4.49 & 5.80 & $4.12(1.14)$ \\
\hline RW & & 7.44 & 10.42 & 13.74 & 18.93 & 22.77 & 27.98 & 34.04 & $19.33(9.62)$ \\
\hline DW & \multirow{3}{*}{$\begin{array}{c}\text { PMMA- } \\
\mathrm{ZnO} \text { NPs } \\
5 \%\end{array}$} & 1.09 & 0.45 & 0.57 & 0.82 & 0.45 & 0.45 & 0.75 & $0.65(0.25)$ \\
\hline $\mathrm{CO}$ & & 4.34 & 3.23 & 3.86 & 6.17 & 4.67 & 5.88 & 9.09 & $5.32(1.96)$ \\
\hline RW & & 4.93 & 21.78 & 25.60 & 24.57 & 33.91 & 45.46 & 49.84 & $29.44(15.23)$ \\
\hline DW & \multirow{3}{*}{$\begin{array}{c}\text { PMMA- } \\
\text { ZnO NPs } \\
7.5 \%\end{array}$} & 0.82 & 1.46 & 2.79 & 5.22 & 4.70 & 6.41 & 5.80 & $3.89(2.20)$ \\
\hline $\mathrm{CO}$ & & 9.83 & 21.00 & 25.96 & 30.77 & 30.12 & 30.89 & 33.60 & $26.02(8.24)$ \\
\hline RW & & 26.22 & 31.40 & 35.16 & 40.90 & 47.79 & 55.01 & 62.66 & $42.73(13.14)$ \\
\hline
\end{tabular}

and red wine were used, the colour changes occurred also over the entire test period with the upward trend. The red wine solution had the greatest influence on the $\triangle \mathrm{E}$ RGB value, which was the highest for the group PMMA$\mathrm{ZnO}$ NPs $7.5 \%$, i.e. 62.66 on the seventh day of the test. The coffee solution discoloured samples to a definitely smaller degree than red wine did, with the mean change for all tested materials achieving 9.66. The individual unit results together with the means for each material and solution are presented in Table 5. Figures 6-9 present the increase in the $\Delta \mathrm{E}$ RGB value for the individual materials over time. Figure 10 shows mean $\triangle \mathrm{E}$ RGB values for the individual pigments and materials. As regards distilled water, a significant change in the colour was observed only for PMMA-ZnO NPs 7.5\% samples, while in the case of other groups the colour changed only slightly. In the $\mathrm{CO}$ solution, changes in the control group, PMMA-ZnO NPs 2.5\%, and PMMA-ZnO NPs czerwone wino, osiągając średnią zmianę dla wszystkich badanych materiałów na poziomie 9,66. Poszczególne jednostkowe wyniki wraz ze średnimi dla każdego materiału i roztworu obrazuje tabela 5. Ryciny 6-9 obrazują przyrost wartości $\Delta \mathrm{E}$ RGB dla poszczególnych materiałów w czasie. Rycina 10 przedstawia średnie wartości $\Delta \mathrm{E}$ RGB dla poszczególnych barwników i materiałów. W wodzie destylowanej znaczna zmiana koloru została zaobserwowana tylko dla próbek PMMA-ZnO $\mathrm{NC} 7,5 \%$, w pozostałych grupach zmiana koloru była niewielka. W roztworze $\mathrm{CO}$ zmiany w grupie kontrolnej, PMMA-ZnO NC2,5\% i PMMA-ZnO NC5\% były porównywalne i oscylowały w zakresie 3,19 - 4,12. W przypadku PMMA-ZnO NC7,5\% współczynnik $\Delta$ E RGB był ponad 6-krotnie wyższy. W medium RW już po 48h dla wszystkich grup różnica koloru była bardzo duża, zmiana była na podobnym poziomie dla PMMA i PMMA$\mathrm{ZnO}$ NC2,5\% i proporcjonalnie wzrastała dla 


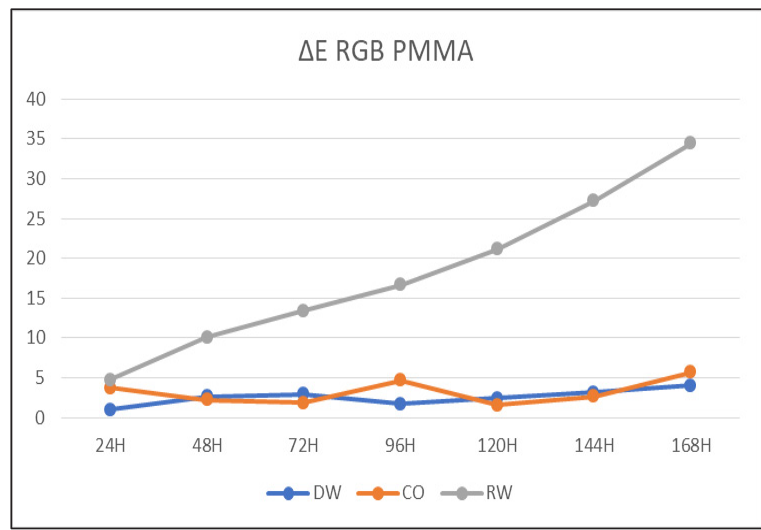

Fig. 6. Change in the $\triangle E$ RGB parameter for PMMA over time depending on the colouring medium used. Ryc. 6. Zmiana parametru $\triangle E$ RGB dla PMMA w czasie w zależności od użytego medium barwiacego.

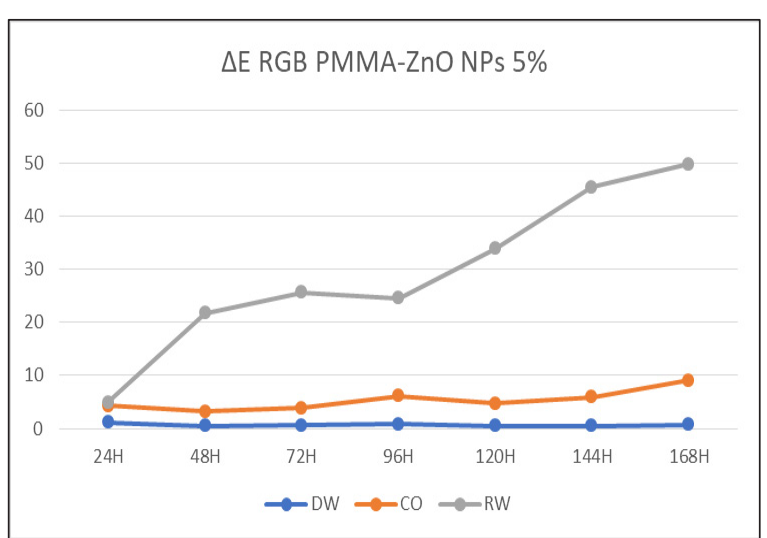

Fig. 8. Change in the $\triangle E$ RGB parameter for PMMA$\mathrm{ZnO} N \mathrm{NP}$ 5\% over time depending on the colouring medium used.

Ryc. 8. Zmiana parametru $\triangle E$ RGB dla PMMA-ZnO NC5\% w czasie w zależności od użytego medium barwiacego.

5\% were comparable and ranged from 3.19 to 4.12. In the case of PMMA-ZnO NPs 7.5\%, the $\triangle \mathrm{E}$ RGB coefficient was over 6 times higher. In the RW medium, the difference in the colour was substantial after only $48 \mathrm{~h}$ for all groups; the change was similar for PMMA and PMMAZnO NPs $2.5 \%$, and increased proportionately for PMMA-ZnO NPs 5\% and PMMA-ZnO NPs $7.5 \%$. The final colours of the samples are illustrated in Fig. 11.

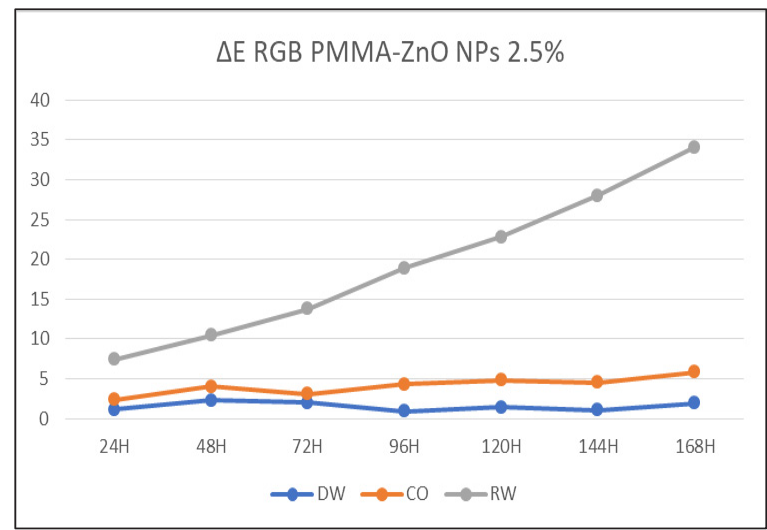

Fig. 7. Change in the $\triangle E$ RGB parameter for PMMAZnO NPs $2.5 \%$ over time depending on the colouring medium used.

Ryc. 7. Zmiana parametru $\triangle E$ RGB dla PMMA-ZnO $N C 2,5 \%$ w czasie $w$ zależności od użytego medium barwiacego.

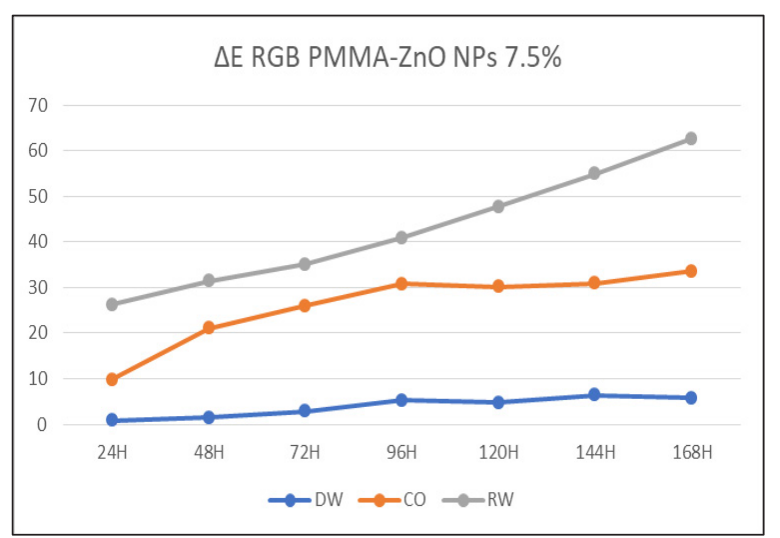

Fig. 9. Change in the $\triangle E$ RGB parameter for PMMAZnO NPs $7.5 \%$ over time depending on the colouring medium used.

Ryc. 9. Zmiana parametru $\triangle E$ RGB dla PMMA-ZnO $N C 7,5 \%$ w czasie $w$ zależności od użytego medium barwiacego.

PMMA-ZnO NC5\% i PMMA-ZnO NC7,5\%. Finalne zabarwienia próbek zostały zobrazowane na rycinie 11 .

\section{Dyskusja}

Ze względu na stale wzrastające zainteresowanie zastosowaniem nanocząstek w stomatologii, dostępnych jest coraz więcej publikacji dotyczących modyfikacji PMMA dla uzyskania 


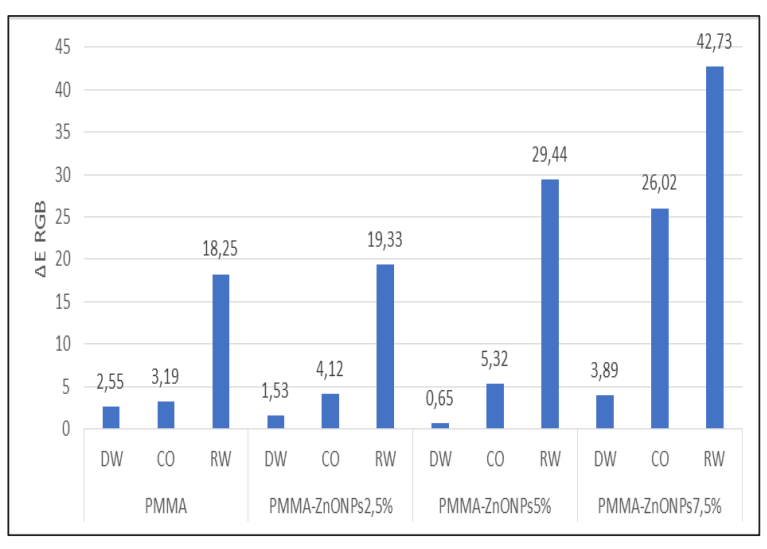

Fig. 10. Mean $\triangle E R G B$ values for the individual groups and materials.

Ryc. 10. Średnie wartości $\triangle E$ RGB dla poszczególnych grup i materiałów.

\section{Discussion}

Due to the continuously growing interest in the application of nanoparticles in dentistry, increasingly more publications on PMMA modification for achieving better microbiological and strength parameters are presented. The properties of new biomaterials modified with e.g. silver (Ag), titanium dioxide $\left(\mathrm{TiO}_{2}\right)$, platinum $(\mathrm{Pt})$, and zinc oxide $(\mathrm{ZnO})$ nanoparticles are well known. ${ }^{4-7,11-13}$ However, an addition of nanoparticles always changes the colour of the material, which in the case of the dark brown colour of silver nanoparticles - considerably impedes or even prevents the application of such a modification in the fabrication of dental prosthesic bases. In their earlier publications, the authors of this study presented the characteristics of the microbiological, mechanical, and cytotoxic properties of the PMMA - nano $\mathrm{ZnO}$ hybrid in detail. ${ }^{4-7}$ An insignificant whitening of the material, which - in the subjective opinion of the authors - was fully acceptable from the aesthetic point of view, was observed even

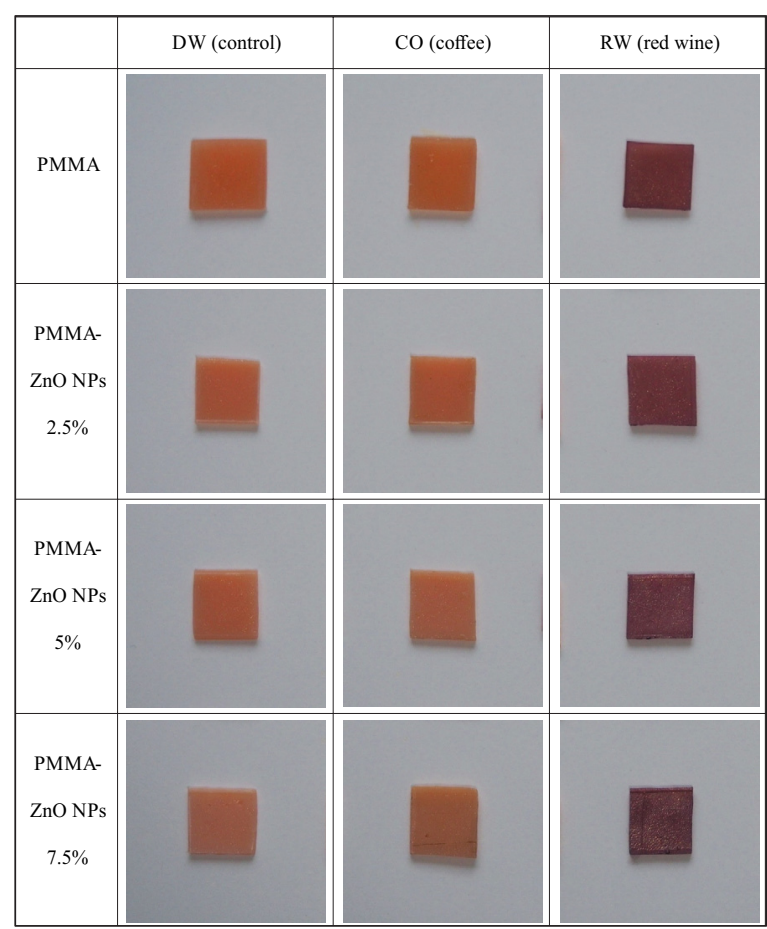

Fig. 11. Photographs of the final colour of the samples after $168 \mathrm{~h}$ of incubation.

Ryc. 11. Zdjęcia fotograficzne finalnego zabarwienia próbek po 168 h inkubacji.

lepszych parametrów mikrobiologicznych jak i wytrzymałościowych. Dobrze poznane są właściwości nowych biomateriałów modyfikowanych nanocząstkami m.in. srebra (Ag), dwutlenku tytanu $\left(\mathrm{TiO}_{2}\right)$, platyny $(\mathrm{Pt})$ czy tlenku cynku (ZnO). ${ }^{4-7,11-13}$ Jednak dodatek nanocząstek zawsze zmienia kolor tworzywa, co w przypadku brunatnego zabarwienia nanocząstek srebra znacznie utrudnia lub nawet uniemożliwia zastosowanie takiej modyfikacji w wykonawstwie płyt protez stomatologicznych. Autorzy pracy we wcześniejszych publikacjach dokładnie scharakteryzowali właściwości mikrobiologiczne, mechaniczne i cytotoksyczne hybrydy PMMA - nano ZnO. ${ }^{4-7}$ Już wtedy zaobserwowano niewielkie zbielenie materiału, które w subiektywnej ocenie autorów było całkowicie akceptowalne $\mathrm{z}$ estetycznego punktu widzenia. Po wykonaniu analizy koloru potwierdzono, iż wraz ze wzrostem zawartości 
at that point. The colour analysis confirmed that in line with the increase in the zinc oxide content in the individual nanocomposites, the individual RGB colour constituents increase proportionally towards the white colour. For a clinical use of a given material, a colour key should be prepared to evaluate the aesthetic effect depending on the gum pigmentation, and to present the expected shade of the prosthesis base to the patient.

It is considered that the acrylic material used for making of dental prostheses is more prone to discolouration than other materials applied in prosthodontics, such as composites and ceramics. ${ }^{14}$ Given proper hygiene and compliance with dentists' recommendations, it is possible to retain the obtained aesthetic effect for many years. Two types of colouring media, i.e. coffee and red wine, were selected arbitrarily in this study to examine the colour stability. According to the literature, both of them belong to materials having the greatest influence on the PMMA colour. ${ }^{15}$ Considerably higher $\Delta \mathrm{E}$ values were observed for samples coloured with red wine. In comparison to pure PMMA, smaller concentrations of nanocomposites behaved similarly or were discoloured to a slightly greater extent. The $7.5 \%$ nanocomposite behaved completely differently: it proved to be much less stable in terms of colour compared to other nanocomposites (Fig. 9).

The PMMA matrix is able to admit and incorporate a certain quantity of $\mathrm{ZnO}$ nanoparticles into its structural lattice in a stable manner. This was illustrated in the tests of $\mathrm{ZnO}$ NPs release to the environment, ${ }^{7}$ where the $7.5 \%$ nanocomposite displayed release of $3.5 \mathrm{mg} / \mathrm{ml}$ after 7 days of incubation, while the release from $2.5 \%$ and $5 \%$ nanocomposites remained at a similar level, i.e. $2.2 \mathrm{mg} / \mathrm{ml}$ and $2.1 \mathrm{mg} / \mathrm{ml}$, respectively. The release increase by $62 \%$ shows that a large quantity of nanoparticles are instable in the polymer matrix and passes to the external environment. tlenku cynku w poszczególnych nanokompozytach poszczególne składowe koloru RGB wzrastają proporcjonalnie w kierunku barwy białej. W przypadku klinicznego wykorzystania danego materiału powinien zostać przygotowany klucz kolorystyczny do oceny efektu estetycznego w zależności od pigmentacji dziąsła, a także do zaprezentowania pacjentowi oczekiwanego odcienia płyty protezy.

Tworzywo akrylowe stosowane w wykonawstwie protez stomatologicznych uznawane jest jako materiał ulegający większym przebarwieniom niż inne materiały stosowane w protetyce stomatologicznej, jak kompozyty czy ceramika. ${ }^{14}$ Przy prawidłowej higienie i przestrzeganiu zaleceń lekarskich udaje się utrzymać uzyskany efekt estetyczny przez długie lata. W pracy arbitralnie wybrano do oceny stabilności koloru dwa rodzaje medium barwiącego $\mathrm{w}$ postaci kawy i czerwonego wina. Oba uznawane w piśmiennictwie jako jedne $\mathrm{z}$ najbardziej oddziałujących na zmianę koloru PMMA. ${ }^{15}$ Zaobserwowano znacznie wyższe wartości $\Delta \mathrm{E}$ dla próbek barwionych czerwonym winem. W porównaniu do czystego PMMA mniejsze stężenia nanokompozytów zachowywały się podobnie lub ulegały niewiele większemu przebarwieniu. Zupełnie inaczej zachowywał się 7,5\% nanokompozyt, który okazał się znacznie mniej stabilny kolorystycznie w porównaniu do pozostałych nanokompozytów (ryc. 9).

Matryca PMMA jest w stanie przyjąć i stabilnie wbudować do swojej sieci strukturalnej pewną ilość nanocząstek $\mathrm{ZnO}$. Zostało to zobrazowane w badaniach uwalniania $\mathrm{ZnO} \mathrm{NC}$ do środowiska, ${ }^{7}$ gdzie 7,5\% nanokompozyt po 7 dniach inkubacji przejawiał uwalnianie na poziomie $3,5 \mathrm{mg} / \mathrm{ml}$, gdy uwalnianie $\mathrm{z}$ nanokompozytów $2,5 \%$ i $5 \%$ było na podobnym poziomie i wynosiło odpowiednio $2,2 \mathrm{mg} / \mathrm{ml}$ i $2,1 \mathrm{mg} / \mathrm{ml}$. Wzrost uwalniania o $62 \%$ pokazuje, iż duża ilość nanocząstek jest niestabilna w matrycy polimerowej i przechodzi do środowiska zewnętrznego. Powstające w polimerze 
Hence, the spaces forming in the polymer might incorporate pigments from the environment and thereby be responsible for a considerable change in the colour.

Another possible nanocomposite discolouration mechanism could be material's absorbability. Along with water absorption, microorganisms and pigments coming from the environment infiltrate the polymer. ${ }^{16}$ In the earlier research by the authors, ${ }^{6}$ it was proved that the nanocomposite absorbability level was up to $2 \%$, which corresponds to the ISO requirements (20795-1,2013 Dentistry-Base polymers-Part 1, Denture base polymers) for dental prostheses. The insignificant fluctuations of absorbability for the individual nanocomposites do not explain the increased change in colour for the $7.5 \%$ nanocomposite. The proneness to discolouration might result also from the nature of zinc oxide itself, as its particles incorporated into the matrix might change colour. This phenomenon is observed frequently in clinical conditions, where $\mathrm{ZnO}$ based dressings left for a longer time discolour into dark brown when in contact with the oral cavity environment.

The conducted tests should be treated as an introduction to further research activities, where the subjective colour evaluation can be replaced with a quantitative analysis in NBS units (Tab. 6) in accordance with the formula proposed by the National Bureau of Standards: $\mathrm{NBS}=\Delta \mathrm{E} \times 0.92$.

In order to apply the aforementioned indicator, the CIE $\mathrm{L}^{*} \mathrm{a} * \mathrm{~b} *$ colour palette should be used. The CIE L*a*b* standard is the standardised colour space proposed by International Commission on Illumination (CIE - Commission internationale de l'éclairage). It is also worth checking the colour stability relative to other media, such as black tea, cleaning tablets, chlorhexidine, and cola, and extend the incubation time to a few months. przestrzenie mogą zatem wbudowywać pigmenty z otoczenia i tym samym być odpowiedzialne za znaczną zmianę koloru.

Kolejnym możliwym mechanizmem przebarwiania nanokompozytów może być nasiąkliwość tworzywa. Wraz z absorpcją wody do wnętrza polimeru wnikają mikroorganizmy, ale także barwniki pochodzące $\mathrm{z}$ otoczenia. ${ }^{16} \mathrm{We}$ wcześniejszych badaniach autorów ${ }^{6}$ udowodniono, iż nasiąkliwość nanokompozytów jest na poziomie do $2 \%$, co odpowiada wymaganiom stawianym przez normy ISO (207951,2013 Dentistry-Base polymers-Part 1, Denture base polymers) dla protez zębowych. Niewielkie wahania nasiąkliwości dla poszczególnych nanokompozytów nie thumaczą zwiększonej zmiany zabarwienia dla 7,5\% nanokompozytu. Tendencja do przebarwiania może wynikać także z samej natury tlenku cynku, którego cząstki wbudowane do matrycy mogą zmieniać kolor. Zjawisko to jest często obserwowane w warunkach klinicznych, gdzie dłużej pozostawione opatrunki na bazie $\mathrm{ZnO}$ ulegają brunatnemu przebarwieniu przy kontakcie ze środowiskiem jamy ustnej.

Przeprowadzone badania należy traktować jako wstęp do dalszej aktywności badawczej, gdzie subiektywnie dokonana ocena koloru może zostać zastąpiona analizą ilościową w jednostkach NBS zgodnie ze wzorem zaproponowanym przez Narodowe Biuro Standardów (ang. National Bureau of Standards): NBS = $\Delta \mathrm{E} \times 0,92$.

Aby zastosować powyższy wskaźnik należy użyć palety kolorystycznej CIE L*a*b*. Standard CIE L*a*b* jest znormalizowaną przestrzenią barw zaproponowaną przez Międzynarodową Komisję Oświetleniową (CIE - Commission internationale de l'éclairage). Warto także sprawdzić stabilność koloru w stosunku do innych mediów jak czarna herbata, tabletki czyszczące, chlorheksydyna czy cola oraz przedłużyć czas inkubacji do kilku miesięcy. 


\section{Conclusions}

1. The modification of PMMA with $\mathrm{ZnO}$ nanoparticles is acceptable in aesthetic terms. However, the slight whitening of the material (particularly for the $2.5 \%$ and $5 \%$ nanocomposite) must be discussed with the patient before its potential clinical application.

2. Due to the lower colour stability of the material, the use of the $7.5 \%$ nanocomposite needs to be confronted with the possible benefits arising from its positive microbiological action.

\section{Wnioski}

1. Modyfikacja PMMA nanocząstkami ZnO jest akceptowalna pod względem estetycznym. Niewielkie zbielenie materiału (szczególnie dla 2,5\% i 5\% nanokompozytu) musi być jednak przedyskutowane z pacjentem przed potencjalnym zastosowaniem klinicznym.

2. Ze względu na mniejszą stabilność kolorystyczną materiału, zastosowanie 7,5\% nanokompozytu musi być skonfrontowane z ewentualnymi zyskami wynikającymi z pozytywnego działania mikrobiologicznego.

\section{References / Piśmiennictwo}

1. Craig $R G$, Powers JM: Restorative Dental Materials. Mosby, London (UK) 2002.

2. Li Z, Sun J, Lan J, Qi Q: Effect of a denture base acrylic resin containing silver nanoparticles on Candida albicans adhesion and biofilm formation. Gerodontology 2016; 33: 209216.

3. Sokołowski K, Szynkowska MI, Pawlaczyk A, Eukomska-Szymańska M, Sokolowski J: The impact of nanosilver addition on element ions release form light-cured dental composite and compomer into $0.9 \% \mathrm{NaCl}$. Acta Biochim Pol. 2014; 61: 317-23.

4. Cierech M, Kolenda A, Grudniak AM, Wojnarowicz J, Woźniak B, Gołaś M, SwobodaKopeć E, Łojkowski W, Mierzwińska-Nastalska $E$ : Significance of polymethylmethacrylate (PMMA) modification by zinc oxide nanoparticles for fungal biofilm formation. Int J Pharm 2016; 510: 323-335.

5. Cierech $M$, Wojnarowicz J, Szmigiel D, Baczkowski B, Grudniak A, Wolska K, Łojkowski W, Mierzwińska-Nastalska E: Preparation and characterization of $\mathrm{ZnO}$ -
PMMA resin nanocomposites for denture bases. Acta Bioeng Biomech 2016; 18: 31-41.

6. Cierech M, Osica I, Kolenda A, Wojnarowicz $J$, Szmigiel D, Łojkowski W, Kurzydłowski $K$, Ariga K, Mierzwińska-Nastalska E: Mechanical and physicochemical properties of newly formed ZnO-PMMA nanocomposites for denture bases. Nanomaterials (Basel) 2018; 8: 305.

7. Cierech M, Wojnarowicz J, Kolenda A, Krawczyk-Balska A, Prochwicz E, Woźniak B, Łojkowski W, Mierzwińska-Nastalska E: Zinc oxide nanoparticles cytotoxicity and release from newly formed PMMA-ZnO nanocomposites designed for denture bases. Nanomaterials (Basel) 2019; 9: 1318.

8. Wojnarowicz J, Opalinska A, Chudoba T, Gierlotka S, Mukhovskyi R, Pietrzykowska $E$, Sobczak K, Lojkowski W: Effect of Water Content in Ethylene Glycol Solvent on the Size of $\mathrm{ZnO}$ Nanoparticles Prepared Using Microwave Solvothermal Synthesis. J Nanomaterials 2016; 2016: 2789871.

9. Wojnarowicz J, Chudoba T, Łojkowski W: 
A Review of Microwave Synthesis of Zinc Oxide Nanomaterials: Reactants, Process Parameters and Morphologies. Nanomaterials 2020; 10: 1086.

10. Polish Center for Accreditation, Testing Laboratories, Accreditation Number: AB 1503. https://www.pca.gov.pl/en/accredited-organizations/accredited-organizations/testing-laboratories/AB\%201503, entity.html

11. Makvandi P, Gu JT, Zare EN, Ashtari B, Moeini A, Tay FR, Niu LN: Polymeric and inorganic nanoscopical antimicrobial fillers in dentistry. Acta Biomater 2020; 101: 69-101.

12. Gad MM, Fouda SM, Al-Harbi FA, Näpänkangas $R$, Raustia A: PMMA denture base material enhancement: a review of fiber, filler, and nanofiller addition. Int $\mathrm{J}$ Nanomedicine 2017; 12: 3801-3812.

13. Gad MM, Abualsaud R: Behavior of PMMA
Denture Base Materials Containing Titanium Dioxide Nanoparticles: A Literature Review. Int J Biomater 2019; 31: 1-14.

14. Elagra MI, Rayyan MR, Alhomaidhi MM, Alanaziy AA, Alnefaie MO: Color stability and marginal integrity of interim crowns: An in vitro study. Eur J Dent 2017; 11: 330-334.

15. Dayan C, Guven MC, Gencel B, Bural C: A Comparison of the Color Stability of Conventional and CAD/CAM Polymethyl Methacrylate Denture Base Materials. Acta Stomatol Croat 2019; 53: 158-167.

16. Kucharski Z: Physical properties of resilient materials in prosthodontics. Prosthodontics 2008; 63: 209-216.

Zaakceptowano do druku: 7.12.2020 r.

Adres autorów: 02-097 Warszawa, ul. Binieckiego 6.

(C) Zarząd Główny PTS 2020. 